\title{
THE MEASUREMENT OF THE IODINE-ACCUMULATING FUNCTION OF THE HUMAN THYROID GLAND
}

\author{
By F. RAYMOND KEATING, JR., J. C. WANG,1 THOMAS J. LUELLEN, 2 \\ MARVIN M. D. WILLIAMS, MARSCHELLE H. POWER, \\ AND WILLIAM M. MCCONAHEY ${ }^{2}$
}

(From the Divisions of Biochemistry, Medicine, and Physics and Biophysical Research, Mayo Clinic and Mayo Foundation, Rochester, Minn.)

(Received for publication July 30, 1948)

At least two distinct mechanisms appear to be responsible for accumulation of iodine by the thyroid gland. The first, called the "iodide trap" by Vanderlaan and Vanderlaan (1), involves the concentration, presumably within the thyroid cells, of inorganic iodide obtained from the circulating blood. The second, called hormonal synthesis, involves the utilization of the trapped iodide for the synthesis of organic iodine compounds (chiefly diiodotyrosine and thyroxine) which are then stored in the colloid in thyroglobulin.

Vanderlaan and Vanderlaan (1), and Taurog, Chaikoff and Feller (2) have shown in the rat that, even after hormonal synthesis has been blocked by an antithyroid drug such as propylthiouracil, the thyroid concentrates relatively large quantities of radioiodine. The radioiodine so concentrated remains in the form of iodide and Taurog and associates have shown that it leaves the thyroid at a rate which parallels the decrease of radioiodine in the blood, suggesting that an equilibrium exists between the two. This ability to concentrate radioiodine can be promptly abolished by the administration of thiocyanate, which thus appears to act as a specific poison to the iodide trap.

The iodide-concentrating function has been studied in the human thyroid by Stanley and Astwood (3), who gave tracer doses of $\mathrm{I}^{181}$ some hours after administration of a dose of mercaptoimidazol or propylthiouracil. Significant concentration of radioiodine occurred in the thyroid, reaching a peak in one to three hours, thereafter decreasing and largely disappearing within 24 hours. Administration of potassium thiocyanate after the curve of iodine concentration in the thyroid had reached a maximum was followed

1 Fellow in Biophysics, Mayo Foundation.

2 Fellow in Medicine, Mayo Foundation. by abrupt disappearance of the radioiodine from the thyroid within an hour.

The foregoing is in marked contrast to the manner of accumulation of radioiodine by the untreated thyroid gland $(4,5)$. The accumulation of radioiodine in the unblocked thyroid can be expressed by an exponential curve which levels off between 24 and 48 hours and thereafter the quantity present in the thyroid diminishes gradually over a period of several weeks. Hyperfunctioning glands accumulate radioiodine both more rapidly and in larger quantities than normal glands and subsequently lose the radioiodine more rapidly than normal glands. Analyses of thyroid tissue removed 48 or more hours after administration of a dose of radioiodine reveal that more than 90 per cent of the radioiodine present is organically combined (6). Taurog and Chaikoff (7) have shown that the untreated thyroid gland of the rat converts the radioiodine which it accumulates to organic form with astonishing rapidity, 95 per cent of the quantity present in the thyroid being organically bound as early as 15 minutes after the dose has been given. The accumulation curve of the untreated thyroid gland may thus be regarded as reflecting both the iodide-trapping and the synthetic function, but it seems probable that both the maximal point in the curve and the rate at which accumulation occurs reflect hormonal synthesis more than trapping.

The accumulation of iodine by the human thyroid as disclosed by radioiodine has been shown to vary significantly in varying states of thyroid activity $(4,8,9)$ and has attracted attention both as an aid in diagnosis of thyroid disease and more importantly as a new approach to the clinical study of normal and disordered thyroid function. It represents a distinctly different aspect of thy- 
roid function than other measures of thyroidal activity ordinarily employed clinically, such as protein-bound iodine, basal metabolic rate and blood cholesterol.

In vivo measurement of the quantity of radioiodine in the thyroid involves a number of technical difficulties. In order to convert the counts recorded by a suitable Geiger counter to absolute terms such as microcuries or percentage of the dose given, in vivo measurements must be compared with suitable standards. Account must be taken of the stability and efficiency of the counting tube employed, the geometric relation of the apparatus to the subject, the depth and dimensions of the thyroid, the radioactivity in other parts of the body and such factors as absorption and scattering of photons by the thyroid and the tissues which surround it. In vivo measurement is thus subject to observational errors of considerable magnitude.

A number of investigators have dealt with these problems. In 1940 Hamilton and Soley (4) made the first attempt to determine the absolute amount of $\mathrm{I}^{131}$ collected in the thyroid. Their method consisted in measuring the radioactivity over the anterior and posterior (seventh cervical vertebra) aspects of the neck. The ratio of these values represented the proportion of radiation from the thyroid which penetrated to the back of the neck. The "correct" value for the radioactivity in the thyroid was calculated from this by comparison with a suitable standard of radioiodine. In 1946 Seidlin, Marinelli and Oshry (10) shielded their Geiger counter with $1.91 \mathrm{~cm}$. of lead and measured the radioactivity through a window in the lead shield. The difference between the reading with the window open and that with the window plugged with a $1.91 \mathrm{~cm}$. thickness of lead represents the radioactivity of the region being measured. The absolute value was then determined by comparing this reading with that of a known amount of $\mathrm{I}^{131}$. In 1947 Quimby and McCune (11) made absolute measurements by placing their Geiger counter directly over the neck and comparing these readings with those of known samples in a "phantom."

The iodine-accumulating function of the thyroid has been estimated from in vivo observations in various ways: 1 ) by measuring the quantity of radioiodine maximally accumulated $(4,8,9)$;
2) by measuring the quantity accumulated in some selected period $(10,11) ; 3)$ by observing the relative form and magnitude of the iodineaccumulation curve $(4,5) ; 4)$ by estimating from this curve an arbitrary accumulation gradient $(12)$; or 5 ) by determining the rate constant of the exponential accumulation curve (5). Since Hamilton and Soley had shown that most of a dose of radioiodine was either collected by the thyroid or excreted in the urine, some observers (13) have employed measurements of the quantity excreted in the urine in a selected period, usually 48 hours, to estimate the proportion of the dose collected by the thyroid. There appears to be need for data regarding the relationships of such diverse observations to one another and their individual validity as quantitative measures of iodine-accumulating function.

Keating, Power, Berkson and Haines (14) estimated from the curve of urinary excretion of radioiodine two values: $(a)$ the asymptotic quantity in the urine, which they termed the "renal fraction"; (b) a rate constant, which they considered to represent the disappearance rate of radioiodine from blood. The product of these values, which they called "renal excretion rate," they regarded as the most direct measure of renal function with regard to iodide excretion. The difference between excretion rate and disappearance rate represented disposal of iodine by all tissues other than the kidneys, and was called "collection rate"; a more exact term would have been "extrarenal disposal rate." In so far as the thyroid is the most important site for the extrarenal disposal of iodide, the latter value should provide an index of the rate of iodine accumulation by the thyroid. In support of the interpretation of Keating and co-workers, McConahey and associates (15) determined the rate of disappearance of radioiodine from blood directly from measurements of samples of plasma and found good agreement with estimates of this value obtained from curves of urinary excretion by the method employed by Keating, Power, Berkson and Haines. Luellen and co-workers (5) observed that the rate constants estimated from curves simultaneously obtained from: 1) in vivo observation of radioiodine in the thyroid in counts per second; 2) measurement of radioactivity in peripheral tissues (the thigh); and 3 ) urinary 
excretion of radioiodine, all appeared to be the same as the rate of disappearance of radioiodine from blood as determined directly. It was suggested therefore that in vivo observations of radioiodine in the thyroid might be analyzed in the same manner as the data for urinary excretion of radioiodine. Thus the product of the asymptotic quantity in the thyroid (expressed as a fraction of the dose given) by the disappearance rate of radioiodine from blood gives the quantity iodineaccumulation rate analogous to the quantity renal excretion rate.

It is the purpose of this communication: 1) to describe an empirical method for measuring in vivo the quantity of radioiodine in microcuries collected by the human thyroid gland; 2 ) to present methods for estimating the iodine-accumulation rates from such data; and 3 ) to compare iodine-accumulation rate with other measures of the iodine-accumulating function of the human thyroid which may be derived from in vivo observations and studies of urinary excretion after oral administration of radioiodine.

\section{METHODS}

Radioiodine emits both beta and gamma radiation. The beta radiation will not penetrate much more than 2 or 3 $\mathrm{mm}$. of tissue before being totally absorbed, whereas a large proportion of the gamma radiation will penetrate the tissue and continue in air for several meters. Since the gamma radiation will be emitted uniformly in all directions, its intensity at any distance from the gland should be inversely proportional to the square of the distance, provided one assumes the thyroid to be small enough to be considered a point source. Hence, by placing the Geiger counter at two different distances, $P$ and $Q$, from the neck one should obtain two intensities, $I_{p}$ and $I_{q}$, which would be inversely proportional to the squares of the distances, $A$ and $B$, from the focus of radiation to the effective portion of the counter. However, the measurable distances, $P$ and $Q$, are only from the surface of the skin to the outer surface of the counter. There remains a nonmeasurable portion, $x$, which represents the depth of the thyroid from the surface of the skin plus the depth of the effective portion of the counter from its surface. It is obvious then that:

$$
\begin{aligned}
& A=P+x, \\
& B=Q+x,
\end{aligned}
$$

where $A$ and $B$ are the true distances. The relation of these quantities to each other is given by the equation

$$
\frac{A^{2}}{B^{2}}=\frac{(P+x)^{2}}{(Q+x)^{2}}=\frac{I_{q}}{I_{p}}
$$

and $x$, and hence $A$ and $B$ can be calculated from it when $P, Q, I_{p}$ and $I_{q}$ have been measured.

To quantitate the measurements in millicuries or microcuries, the foregoing procedure is first used with a known standard of $\mathrm{I}^{\mathbf{1 3 1}}$. The Geiger counter being thus calibrated, it is possible to compute the amount of $\mathrm{I}^{131}$ in the thyroid in millicuries or microcuries. It must be added that the background radiation is measured after each setting with a lead cylinder $5 \mathrm{~cm}$. long and $9 \mathrm{~cm}$. in diameter (which absorbs more than 99 per cent of the radiation going from the thyroid to the counter) interposed between the area that is being measured and the counter. This reading includes the cosmic radiation, radiation from the thyroid which has been scattered into the counter from other parts of the body, and direct radiation from $\mathrm{I}^{131}$ located in parts of the body other than the area being measured. The measurements were carried out with the apparatus and general procedure previously described by Luellen and associates (5). An empirical correction was made for radioiodine in the neck and not in the thyroid by subtracting twice the value of radioactivity recorded in the thigh. Except in the case of comparatively small accumulation in the thyroid, the latter correction is relatively insignificant.

To determine the extent to which geometric relations, absorption and backscatter affect the measurements, samples of $\mathrm{I}^{131}$ solution of similar activity but of different diameters were embedded in paraffin phantoms $(1,3$ and $6 \mathrm{~cm}$. diameter and $0.5 \mathrm{~cm}$. deep). It was found that when distances $(P$ and $Q$ ) of 25 and $45 \mathrm{~cm}$. were used the "inverse-square" relationship was valid to within $\pm \mathbf{5}$ per cent. When the $I^{131}$ was not more than $3.5 \mathrm{~cm}$. below the surface, absorption of the radiation by the paraffin above the solution was compensated for by the backscatter from below and lateral to the source. For depths greater than $3.5 \mathrm{~cm}$. the absorption was greater than the backscatter and the apparent amount of radioactivity decreased approximately 4 per cent per centimeter of paraffin. Hence it would appear that this method of determining the amount of $\mathrm{I}^{131}$ in the thyroid should give results which are correct to within \pm 15 per cent.

Serial in vivo observations were made of 30 subjects including 11 patients who had myxedema, ${ }^{3}$ five euthyroid patients who had low-grade thyroid tumors, seven patients who had adenomatous goiter without hyperthyroidism and seven patients who had exophthalmic goiter. One or more in vivo observations were made on 26 addi-

3 The 11 cases of myxedema included in this study were all instances of severe spontaneous or postoperative myxedema in which in vivo studies did not show any measurable accumulation of radioiodine in the thyroid region. Certain cases of myxedematous states have been observed in which varying degrees of iodine accumulation, sometimes of surprising extent, were observed in the thyroid. For the most part these included cases of thyroiditis, struma lymphomatosa and cyanate goiter. Such cases have been omitted from this study and will be made the subject of subsequent reports. 
tional persons: 11 euthyroid patients who had thyroid tumors, six patients who had adenomatous goiter without hyperthyroidism and nine patients who had exophthalmic goiter. In all instances, the urine was carefully collected and analyzed for radioiodine in the manner described by Keating and associates (14).

As in previous studies, both tracer and therapeutic doses are included in the series, careful comparison of the behavior of tracer versus therapeutic amounts in patients receiving both having failed to disclose consistent or significant differences either in the quantity of iodine initially accumulated by the thyroid or in the kinetic relationships involved during the first day or two after administration of the dose.

In the interest of clarity the various values employed in this paper may be defined as follows: From the curve of urinary excretion of radioiodine are derived (1) the renal fraction $\left(Q_{w} f\right)$, defined as the asymptotic $(t=$ infinity) quantity of radioiodine excreted in the urine expressed as a fraction of the dose; (2) the disappearance rate $(r)$, defined as the proportional rate at which radioiodine disappears from the blood into all sites of disposal; (3) the renal excretion rate, defined as the proportional rate of excretion of radioiodine by the kidneys (This is obtained by taking the product of the renal fraction and the disappearance rate $\left[Q_{u} f \times r\right]$.); (4) the extrarenal disposal rate, which in previous publications was called "collection rate," defined as the proportional rate of disappearance of radioiodine into all sites other than the urine. This is obtained by subtracting the renal excretion rate from the disappearance rate ( $\left.r\left[1-Q_{u} f\right]\right)$.

From the curve of accumulation of the radioiodine by the thyroid as measured in vivo can be obtained (5) the thyroid fraction $\left(Q_{t} f\right)$ defined as the asymptotic $(t=$ infinity) quantity of radioiodine accumulated by the thyroid expressed as a fraction of the dose; (6) the disap- pearance rate $(r)$ defined as in the previous paragraph; (7) the iodine-accumulation rate, defined as the proportional rate of accumulation of iodine by the thyroid (This is obtained by taking the product of the thyroid fraction and the disappearance rate $[Q, f \times r]) ;.(8)$ the extrathyroidal disposal rate, defined as the proportional rate of disappearance of radioiodine into all sites other than the thyroid. This is obtained by subtracting the accumulation rate from the disappearance rate $(r[1-Q, f])$.

The renal fraction and the disappearance rate were estimated from observations on urine as previously described (14). The thyroid fraction and the disappearance rate have been estimated from in vivo observations of the thyroid as described by Luellen and his associates (5), except that the quantities in the thyroid have been expressed in actual terms as percentage of dose instead of in relative terms as counts per second.

Reference will also be made to (9) accumulation gradient, a term coined by Stanley and Astwood (12) and defined by them as the slope of a line obtained by plotting thyroid accumulation of radioiodine in counts per second per 100 microcuries of dose against the square root of time. The value is obtained by dividing the increase in counts per second during a given period against the number resulting from subtracting the square root of time in minutes at the beginning of the period from the square root of time in minutes at the end of the period.

\section{RESULTS}

In Table I are summarized the means of the various values estimated from the curve of urinary excretion and from the curve of in vivo observations obtained simultaneously over the thyroid. For comparison are included (10) the mean quantities of iodine observed in the thyroid 12

TABLE I

Comparison of various values derived from serial observations of urinary excretion and thyroidal accumulation of radioiodine

\begin{tabular}{|c|c|c|c|c|c|c|c|c|c|c|c|c|}
\hline \multirow[b]{2}{*}{ Diagnosis } & \multirow[b]{2}{*}{ Cases } & \multirow[b]{2}{*}{$\begin{array}{c}\text { Basal } \\
\text { metabolic } \\
\text { rate }\end{array}$} & \multicolumn{4}{|c|}{ Values from urinary excretion curve } & \multicolumn{5}{|c|}{ Values obtained from thyroidal curve } & \multirow{2}{*}{$\begin{array}{c}(10) \\
\text { Quantity } \\
\text { in } \\
\text { thyroid } \\
\text { after } \\
12 \text { hours }\end{array}$} \\
\hline & & & $\begin{array}{c}(1)^{*} \\
\text { Renal } \\
\text { fraction } \\
\left(Q_{w} f\right)\end{array}$ & $\begin{array}{c}(2) \\
\text { Disap- } \\
\text { pearance } \\
\text { rate } \\
(r)\end{array}$ & $\begin{array}{c}(3) \\
\text { Renal } \\
\text { excretion } \\
\text { rate } \\
\left(Q_{*} f \times r\right)\end{array}$ & $\begin{array}{c}(4) \\
\text { Extra- } \\
\text { renal } \\
\text { disposal } \\
\text { rate } \\
(r[1-Q=f])\end{array}$ & $\begin{array}{c}(5) \\
\text { Thyroid } \\
\text { fraction } \\
\left(Q_{t} f\right)\end{array}$ & $\begin{array}{c}(6) \\
\text { Disap- } \\
\text { pearance } \\
\text { rate } \\
(r)\end{array}$ & $\begin{array}{c}(7) \\
\text { Accumu- } \\
\text { lation } \\
\text { rate } \\
\left(Q_{t} f \times r\right)\end{array}$ & $\begin{array}{c}(8) \\
\text { Extra- } \\
\text { thyroidal } \\
\text { disposal } \\
\text { rate } \\
(r[1-Q, f])\end{array}$ & $\begin{array}{c}(0) \\
\text { Accumu- } \\
\text { lation } \\
\text { gradient }\end{array}$ & \\
\hline $\begin{array}{l}\text { Myxedemat } \\
\text { Euthyroid pa- } \\
\text { tients who had }\end{array}$ & 11 & $\begin{array}{c}\text { per cent } \\
-26.7 \pm 3.2 \ddagger\end{array}$ & $\begin{array}{c}\text { per cent } \\
\text { of dose } \\
86.4 \pm 2.0\end{array}$ & $\begin{array}{c}\text { per centl } \\
\text { hour } \\
5.6 \pm 0.4\end{array}$ & $\begin{array}{c}\text { per cent } \\
\text { hour } \\
4.7 \pm 0.5\end{array}$ & $\begin{array}{c}\text { per centl } \\
\text { hour } \\
0.9 \pm 0.3\end{array}$ & $\begin{array}{c}\text { per cent } \\
\text { of dose } \\
0 \\
\end{array}$ & $\begin{array}{c}\text { per cent/ } \\
\text { hour }\end{array}$ & $\begin{array}{c}\text { per centl } \\
\text { hour }\end{array}$ & $\begin{array}{l}\text { per centl } \\
\text { hour }\end{array}$ & & $\begin{array}{c}\text { per cent } \\
\text { of dose } \\
0\end{array}$ \\
\hline $\begin{array}{l}\text { Adenomatous } \\
\text { goiter without } \\
\text { hyperthy- } \\
\text { roidism } \\
\text { Exophthalmic } \\
\text { goiter }\end{array}$ & $\begin{array}{l}7 \\
7\end{array}$ & $\begin{array}{r}-2.9 \pm 2.3 \\
+32.7 \pm 2.6\end{array}$ & $\left|\begin{array}{l}57.3 \pm 6.3 \\
31.2 \pm 5.6\end{array}\right|$ & $\begin{array}{l}14.0 \pm 1.0 \\
29.7 \pm 6.5\end{array}$ & $\begin{array}{l}7.0 \pm 1.0 \\
7.8 \pm 0.8 \\
8.0 \pm 1.0\end{array}$ & $\begin{array}{r}6.2 \pm 1.3 \\
21.6 \pm 6.3\end{array}$ & $\begin{array}{l}29.5 \pm 4.7 \\
56.3 \pm 5.8\end{array} \mid$ & $\left|\begin{array}{l}14.2 \pm 1.7 \\
34.1 \pm 6.7\end{array}\right|$ & $\begin{array}{r}4.6 \pm 1.3 \\
20.2 \pm 5.6\end{array}$ & $\begin{array}{r}9.6 \pm 0.5 \\
13.9 \pm 2.6\end{array}$ & $\mid \begin{array}{r}6.0 \pm 1.5 \\
24.9 \pm 5.1\end{array}$ & $\begin{array}{l}23.6 \pm 4.2 \\
49.8 \pm 5.0\end{array}$ \\
\hline
\end{tabular}

* The numbers refer to the definitions given in text above.

$\dagger$ The cases of myxedema selected all failed to show measurable collection in thyroid. See Footnote 3 .

$\ddagger$ The values given are the means and the standard errors of the means. 
hours after administration of the dose, and the accumulation gradient as defined by Stanley and Astwood (12).

Of the ten values shown in Table $I$, eight vary significantly with variations in thyroidal activity and two do not. Renal excretion rate (3) is regarded as a measure of renal function with respect to iodine. Extrathyroidal rate of disposal ( 8 ) measures the rate of disposal of iodine by all tissues other than thyroid, including kidneys. As noted elsewhere, the mean disappearance rates ( 2 and 6 ) obtained by the two types of observations do not differ significantly.

Attention is called particularly to the magnitude by which the mean values differ in various states of thyroid activity. The renal fraction (1) is twice as high in the euthyroid patients as in the group having exophthalmic goiter but only a fourth higher in myxedema than in the euthyroid patients. The thyroid fraction (5) on the other hand is 3.0 times as great in exophthalmic goiter as in the euthyroid group. It will be noted that the quantity of iodine actually observed in the thyroid after an arbitrarily selected interval (12 hours), also varies by about the same amount, being 3.4 times as great in exophthalmic goiter as in the euthyroid group.

Disappearance rate (2 and 6 ) is 2.6 times as high in exophthalmic goiter as in the euthyroid group, extrarenal disposal rate (4) is 5.5 times as high in exophthalmic goiter as in the euthyroid group, while the accumulation rate (7) differs by a factor of 8.4 and Stanley and Astwood's accumulation gradient (9) by a factor of 8.1 .

It will be noted that the values for the group having adenomatous goiter without hyperthyroidism are to some degree intermediate between euthyroid and hyperthyroid groups. It was observed that large adenomatous goiters tended to show increased avidity for iodine even in the absence of clinical evidences of hyperthyroidism.

The foregoing data were accumulated from serial in vivo observations obtained over a period of several days. Such serial observations provide a method of evaluating disappearance rate as described by Luellen and associates (5) and also for assigning a value to the thyroid fraction. Sufficient observation to enable one to construct a reasonably accurate curve is quite time-consuming both to patient and to observer and ties up the apparatus for the greater part of two days. Even so, there is likely to be an annoying hiatus in the curve unless observations are also made during the night. For these reasons a less timeconsuming method for evaluating iodine-accumulation rate might have some advantages.

Since the rate of disappearance of radioiodine from blood can be calculated from measurements over thyroid, peripheral tissues, urine or blood, one should be able to calculate with reasonable accuracy the value of thyroid accumulation rate from (a) a single accurate measurement over the thyroid made during the period of radioiodine accumulation, and $(b)$ the value for disappearance rate calculated from urine as described elsewhere. The thyroid fraction can be approximated from the curve of urinary excretion and a single in vivo measurement from the equation $Q_{t} f / Q_{u} f=Q_{t} / Q_{u}$ where $Q_{t}$ is the quantity measured in the thyroid, $Q_{u}$ the quantity excreted in the urine up to the time of the thyroid measurement, $Q_{t} f$ the thyroid fraction and $Q_{u} f$ the renal fraction. Accumulation rate estimated in this way is probably less accurate than an estimate based on serial observations in vivo, for the reason that a value based on a series of such measurements is less dependent on the error of any one observation than is a value based on a single observation.

In Table II are shown mean values for accumulation rate for the same groups of cases in-

TABLE II

Comparison of accumulation rates estimated by two methods

\begin{tabular}{c|c|c|c|c}
\hline \hline Group & Cases & \multicolumn{2}{|c|}{ Accumulation rate } & \\
\cline { 2 - 4 } & & $\begin{array}{c}\text { Estimated } \\
\text { from serial } \\
\text { in vivo } \\
\text { observations } \\
\text { over the } \\
\text { thyroid }\end{array}$ & $\begin{array}{c}\text { Estimated } \\
\text { from } \\
\text { urinary } \\
\text { curve and } \\
\text { one in vivo } \\
\text { observation } \\
\text { over the } \\
\text { thyroid }\end{array}$ & $\begin{array}{c}\text { Means of } \\
\text { individual } \\
\text { differences }\end{array}$ \\
\hline $\begin{array}{c}\text { Euthyroid } \\
\text { patients who } \\
\text { had thyroid } \\
\text { tumors }\end{array}$ & 5 & $2.4 \pm 0.7 *$ & $2.6 \pm 0.8$ & $+0.2 \pm 0.2$ \\
$\begin{array}{c}\text { Adenomatous } \\
\text { goiter with- } \\
\text { out hyper- } \\
\text { thyroidism }\end{array}$ & 7 & $4.6 \pm 1.3$ & $4.2 \pm 0.9$ & $-0.4 \pm 0.5$ \\
$\begin{array}{c}\text { Exophthalmic } \\
\text { goiter }\end{array}$ & 7 & $20.2 \pm 5.6$ & $18.0 \pm 4.4$ & $-2.2 \pm 1.6$ \\
\hline
\end{tabular}

* The values given are the means and the standard errors of the means. 
TABLE III

Accumulation rates estimated in a second series of patients from urinary excretion and single observations in vivo over the thyroid

\begin{tabular}{|c|c|c|c|c|c|c|}
\hline Group & Cases & $\begin{array}{c}\text { Basal } \\
\text { metabolic } \\
\text { rate }\end{array}$ & $\begin{array}{c}\text { (1) } \\
\text { Renal } \\
\text { fraction }\end{array}$ & $\begin{array}{c}(2) \\
\text { Disap- } \\
\text { pearance } \\
\text { rate }\end{array}$ & $\begin{array}{l}(4) \\
\text { Extra- } \\
\text { renal } \\
\text { disposal } \\
\text { rate }\end{array}$ & $\begin{array}{c}(7) \\
\text { Accumu- } \\
\text { lation } \\
\text { rate }\end{array}$ \\
\hline $\begin{array}{l}\text { Euthyroid patients } \\
\text { who had thyroid } \\
\text { tumors } \\
\text { Adenomatous } \\
\text { goiter without } \\
\text { hyperthyroidism } \\
\text { Exophthalmic } \\
\text { goiter }\end{array}$ & $\begin{array}{l}6 \\
9\end{array}$ & $\begin{array}{c}\text { per cent } \\
-4.0 \pm 3.2 * \\
+0.8 \pm 2.1 \\
+32.9 \pm 3.4\end{array}$ & $\begin{array}{l}\text { per cent } \\
\text { of dose } \\
64.9 \pm 0.8 \\
50.9 \pm 8.2 \\
27.8 \pm 6.1\end{array}$ & $\begin{array}{c}\begin{array}{c}\text { per cent/ } \\
\text { hour }\end{array} \\
9.6 \pm 0.3 \\
11.8 \pm 2.1 \\
28.6 \pm 5.3\end{array}$ & $\begin{array}{c}\begin{array}{c}\text { per cent/ } \\
\text { hour }\end{array} \\
3.4 \pm 0.2 \\
6.2 \pm 2.2 \\
22.8 \pm 6.3\end{array}$ & $\begin{array}{c}\begin{array}{c}\text { per cont/ } \\
\text { hour }\end{array} \\
2.6 \pm 0.3 \\
4.7 \pm 2.0 \\
19.8 \pm 5.5\end{array}$ \\
\hline
\end{tabular}

* The values given are the means and the standard errors of the means.

cluded in Table I, comparing estimations based entirely on in vivo measurements with estimations in the same cases made in the manner just enumerated. The values obtained with each method agree fairly well with each other.

Table III shows accumulation rates for a second group of cases, estimated from urinary excretion curves and single in vivo observations over the thyroid. For comparison the various values obtained from the urine alone are also included. The same relationships noted in the first group (Table I) hold here; namely, that the most striking differences are encountered in the accumulation rate and the extrarenal disposal rate.

If all of the iodine given to the patient either appeared in the urine or was collected by the thyroid, then (a) renal fraction (1) plus thyroid fraction (5) should equal 100 per cent; (b) extrarenal disposal rate (4) should equal accumulation rate $(7)$; and (c) extrathyroidal disposal rate (8) should equal renal excretion rate (3). However, it is found that this is not the case. Renal plus thyroid fractions consistently total less than 100 per cent, extrarenal disposal rates are consistently larger than accumulation rates, and extrathyroidal disposal rates are consistently larger than renal excretion rates. The difference between the sum of renal and thyroid fractions and 100 per cent will provide some measure of the fraction of the dose disposed of elsewhere than in kidneys or thyroid. The rate of disposal by tissues other than kidneys or thyroid can be approximated by extrarenal disposal rate (4) minus accumulation rate $(7)$ or alternatively by extra- thyroidal disposal rate $(8)$ minus excretion rate (3). The "tissue rate" so estimated by either method for any case would have the same value providing the estimate of disappearance rate obtained from thyroid is identical with that obtained from urine, a circumstance which is unlikely owing to the errors in the observations.

In Table IV are given the means of the foregoing values for those cases in which serial observations over the thyroid were made. It is of interest that the fraction of the dose unaccounted for is about the same (12.5 per cent to 13.6 per cent) in all four groups of cases and that the mean rate of extrarenal disposal for the group having myxedema is of about the same order of magnitude as the estimates of "tissue rates" for the other groups. These values would represent any radioiodine excreted in feces, sweat or expired air as well as any radioiodine fixed in tissues such as muscle or liver. These values will also, unfortunately, bring into prominence any loss of iodine in the collection of urine, any error resulting from the methods of measurement employed and any error inherent in the methods by which the various values were derived. Estimates of disposal of iodine by tissues other than kidneys and thyroid vary considerably from case to case, and for the reasons given they must be regarded as relatively inaccurate and probably too high. On this account it is not apparent from this small

TABLE IV

Disposal of iodine by tissues other than kidneys and thyroid

\begin{tabular}{l|c|c|c|c}
\hline Group & Cases & $\begin{array}{c}\text { Fraction } \\
\text { of } \\
\text { dose un- } \\
\text { accounted } \\
\text { for }\end{array}$ & $\begin{array}{c}\text { Extra- } \\
\text { renal } \\
\text { disposal } \\
\text { rate (4)- } \\
\text { accumu- } \\
\text { lation } \\
\text { rate (7) }\end{array}$ & $\begin{array}{c}\text { Extra- } \\
\text { thyroidal } \\
\text { disposal } \\
\text { rate (8)- } \\
\text { renal } \\
\text { excretion } \\
\text { rate (3) }\end{array}$ \\
\hline $\begin{array}{c}\text { Myxedema* } \\
\begin{array}{c}\text { Euthyroid patients } \\
\text { who had thyroid } \\
\text { tumors }\end{array}\end{array}$ & 11 & $\begin{array}{c}13.6 \pm 2.0 \\
\text { per cent } \\
\text { of dose }\end{array}$ & $\begin{array}{c}\text { per cent/ } \\
\text { hour }\end{array}$ & $\begin{array}{c}0.9 \pm 0.3 \\
\text { per cent/ } \\
\text { hour }\end{array}$ \\
$\begin{array}{c}\text { Adenomatous goiter } \\
\text { without hyper- } \\
\text { thyroidism }\end{array}$ & 7 & $13.1 \pm 2.9$ & $1.5 \pm 0.4$ & $2.3 \pm 1.1$ \\
$\begin{array}{c}\text { Exophthalmic } \\
\text { goiter }\end{array}$ & 7 & $12.5 \pm 4.3$ & $1.4 \pm 1.1$ & $5.9 \pm 2.1$ \\
\hline
\end{tabular}

* In the group having myxedema the values given are (a) 100 per cent - renal fraction and (b) extrarenal disposal rate alone, there being no thyroidal accumulation.

$\dagger$ The values given are the means and the standard errors of the means. 
series whether any significance should be attached to the relatively greater value for tissue rates in cases of exophthalmic goiter.

\section{COMMENT}

Previous studies have dealt with various aspects of the kinetic behavior of radioiodine, on the basis of observations of urinary excretion of radioiodine (14), the concentration of radioiodine in the blood (15) and the quantity of radioiodine in the thyroid or peripheral tissues as measured in vivo in counts per second (5). The present study adds to these some in vivo observations which are expressed in absolute terms. The results enumerated permit a comparison of various measures in a search for the most appropriate and precise method of evaluating quantitatively the capacity of the thyroid to accumulate iodide by means of observations made with radioiodide. An ideal measure of this function of the thyroid should be expressed in terms which are independent of the dose of radioiodine given and should reflect the accumulation of iodide by the thyroid alone, uninfluenced by irrelevant changes which might occur in the kidneys or in other tissues, or in water exchange.

Measurement of the quantity of radioiodine in thyroid or urine. Direct measurement in vivo of the quantity of radioiodine in the thyroid after some interval of time might at first glance appear the most appropriate measure of iodine-accumulating function. This is not true for the reason that the thyroid must in effect compete with the kidneys and other tissues for the limited quantity of iodine provided in the tracer dose. The quantity of radioiodine accumulated by the thyroid in any given period, as well as the quantity eventually or asymptotically accumulated, is a relative quantity, depending on the function of the kidneys and other tissues as well as on the iodine-accumulating function of the thyroid itself. On this basis even if the thyroid function with respect to iodine accumulation remains quite constant, a variation in function of the kidneys or perhaps of other iodine-collecting tissue should alter the picture of iodine accumulation by the thyroid. Thus, if the ability of the kidneys to excrete iodine was decreased, the amount of iodine accumulated in any given time by the thyroid should increase and so should the total amount eventually accu- mulated. These relationships may be important even if pathologic alteration of the function of the kidneys or other tissues with respect to iodine is not involved. In euthyroid persons, the kidneys and other tissues account for the disposal of three-fourths or more of a tracer dose of radioiodine and quite physiologic fluctuations in the function of the kidneys or other tissues might modify significantly the quantity of radioiodine accumulated by the thyroid.

These considerations may account for the fact that, as judged by the comparative magnitude of the variations encountered in various states of thyroidal activity, neither the quantity of radioiodine in the thyroid at a selected time ( 12 hours) nor the asymptotic quantity in the thyroid (the thyroid fraction [5]) appears as significant as several other measures of iodine-accumulating function listed in Tables I and III. Measurements of the quantity of radioiodine in the urine, probably because they reflect the quantity in the thyroid indirectly, appear less significant.

Measurements of rates. Disappearance rate (2) reflects accumulation of radioiodine by the thyroid only indirectly, since it measures the disappearance of radioiodine as iodide from the blood into all tissues into which it goes, including kidneys and other tissues as well as thyroid. Disappearance rate varies from one group to another (Table I) by about the same degree as the quantity in the thyroid after 12 hours or the thyroid fraction (5).

Extrarenal disposal rate (4) is one step closer to a direct measure of iodine-accumulating function. It measures the disposal of radioiodine by all tissues other than the kidneys. Inasmuch as the thyroid is the most important of these, except in hypothyroid or athyroid persons, it appears to be a fairly reliable index of iodine-accumulation rate, subject only to inaccuracies resulting from variations in the removal of iodine by tissues other than the kidneys. It is perhaps somewhat paradoxical but nevertheless it appears to be true that extrarenal disposal rate, which is estimated from urine, appears a more valid measure of iodine-accumulating function in cases of normal or increased thyroid activity than direct estimation of the quantity of radioiodine in the thyroid. This is not the case when thyroid activity is reduced or absent. 
The accumulation rate (7), estimated directly from serial observations in vivo or approximated from the curve of urinary excretion and a single observation in vivo during the period of iodine accumulation, appears to measure iodine-accumulating function directly, uninfluenced by variations in the function of the kidneys or of other tissues. Together with accumulation gradient it appears the most significant of the various measures enumerated in Tables I and III.

Accumulation gradient. The value which Stanley and Astwood (12) called "accumulation gradient" does not correspond either to disappearance rate or to accumulation rate as we have defined them, although it most nearly approximates the latter. The numerical value given to accumulation gradient is an arbitrary number without quantitative relation to the physiologic processes involved. Since it is a value obtained by dividing counts per second by a function of time, the numerical value of the accumulation gradient will vary with differences in the sensitivity of the counting apparatus, differences in the quantity of radioactivity given in the tracer and differences in the geometric relationship of counter to thyroid. These factors can all theoretically at least be corrected for, but it is likely that they will make it difficult to obtain figures in different laboratories which can be compared with one another. The mean value of accumulation gradient in the euthyroid cases shown in Table I is only about a third as large as Stanley and Astwood's figures, despite the fact that the values were corrected for both quantity of radioactivity and geometric relationship. This lack of agreement probably reflects differences in the sensitivity of the apparatus, and perhaps also a difference in the value of the microcurie employed as a standard.

The accumulation gradient has the great advantage that it can be obtained without continuing observations long enough to evaluate the asymptotic value of the accumulation curve. This advantage was employed by Stanley and Astwood to evaluate the antithyroid potency of various drugs under conditions which would have precluded direct estimations of iodine-accumulation rate, since the accumulation curve was modified by the addition of the drug a few hours after the experiment had been begun.
Significance of accumulation rate. The radioactivity contained in the tracer given to a patient initially may be regarded as labeling only the quantity of iodide given in the dose. Once sufficient time has elapsed for absorption to have occurred and for the dose of labeled iodide to reach equilibrium in the blood and the body fluids, the radioactivity in the tracer may be considered to label all of the iodine in the blood and body fluids which is in the same chemical form as the dose given (that is, as iodide). On this basis accumulation rate measures the proportion of all of the iodide in blood and body fluids which is being accumulated in the thyroid per hour. The iodine-accumulation rate of the thyroid is thus expressed in terms which are independent of the tracer dose given as well as independent of variations in the removal of iodine by other tissues, such as the kidneys.

Accumulation rate has a connotation somewhat similar to "clearance" as used in studies of renal function. It could be used interchangeably with clearance providing the volume of distribution of iodine in blood and in the fluids of the body in equilibrium with the blood did not vary significantly. Accumulation rate relates the iodineaccumulating function to the total stock of available iodide in the body as a whole. It is more reasonable to suppose, however, that this function is more directly related to the concentration of iodide in the blood circulating through the thyroid than to the total quantity of iodide in the blood and in distant parts of the organism which may be in equilibrium with the blood. Furthermore, it is likely that the volume of distribution of iodide may vary in different persons and in various pathologic conditions. For these reasons, thyroidal iodide clearance, expressed as the volume of plasma cleared of its iodide content per minute, may prove to be a more accurate measure of iodine-accumulating function than accumulation rate.

Accumulation rate is estimated from observations on the thyroid alone, whereas clearance of iodide by the thyroid must be derived from simultaneous observations on both thyroid and blood. Thyroidal iodide clearance can be obtained by multiplying accumulation rate by the volume of distribution of iodide, if the latter is known. In the absence of a measure of volume of distribution, 
TABLE V

Comparison of accumulation rate, thyroidal clearance of iodide and volume of distribution of iodide

\begin{tabular}{|c|c|c|c|c|c|c|}
\hline Case & Diagnosis & $\begin{array}{l}\text { Basal } \\
\text { meta- } \\
\text { bolic } \\
\text { rate }\end{array}$ & $\begin{array}{c}\text { Iodine } \\
\text { accumu } \\
\text { lation } \\
\text { rate }\end{array}$ & $\begin{array}{l}\text { Thyroid } \\
\text { iodine } \\
\text { clear- } \\
\text { ance }\end{array}$ & \multicolumn{2}{|c|}{$\begin{array}{l}\text { Volume } \\
\text { distribution } \\
\text { of iodine }\end{array}$} \\
\hline \multirow[b]{2}{*}{1} & \multirow[b]{2}{*}{$\begin{array}{l}\text { Adenomatous } \\
\text { goiter with- } \\
\text { out hyper- } \\
\text { thyroidism }\end{array}$} & $\begin{array}{l}\text { per } \\
\text { cent }\end{array}$ & $\begin{array}{c}\text { percent } \\
\text { hour }\end{array}$ & $c c . / m i n$. & $\begin{array}{l}\text { total } \\
\text { liters }\end{array}$ & $c c . / \mathrm{kg}$. \\
\hline & & -14 & 3.6 & 13.5 & 22.8 & 330 \\
\hline 2 & $\begin{array}{l}\text { Adenomatous } \\
\text { goiter with- }\end{array}$ & & & & & \\
\hline \multirow[t]{2}{*}{3} & $\begin{array}{c}\text { thyroidism } \\
\text { Adenomatous }\end{array}$ & -5 & 1.0 & 3.0 & 18.0 & 240 \\
\hline & $\begin{array}{l}\text { goiter with- } \\
\text { out hyper- } \\
\text { thyroidism }\end{array}$ & +5 & 0.6 & 2.2 & 220 & 414 \\
\hline \multirow[t]{2}{*}{4} & Exophthalmic & 120 & & & & \\
\hline & Exophthalmic & +28 & 23.2 & 68.0 & 17.6 & 290 \\
\hline 5 & goi & +42 & 10.0 & 20.4 & 12.2 & 210 \\
\hline 6 & goiter & +34 & 24.6 & 69.0 & 16.9 & 270 \\
\hline 7 & $\begin{array}{l}\text { Exophthalmic } \\
\text { goiter }\end{array}$ & +29 & 50.7 & 228.1 & 27.0 & 500 \\
\hline 8 & $\begin{array}{l}\text { Exophthalmic } \\
\text { goiter }\end{array}$ & +21 & 13.5 & 28.8 & 12.8 & 230 \\
\hline
\end{tabular}

the thyroidal clearance of iodide may be estimated by a simple modification of the standard formula for renal clearance. ${ }^{4}$. In Table $\mathrm{V}$ are given values for thyroidal iodide clearance (determined directly) and iodine accumulation rates for eight cases in which both blood and thyroid data were available. Also given are values for the volume of distribution of iodide estimated from clearances and accumulation rates. ${ }^{5}$ It will be observed that

4 The standard formula for renal clearance

(concentration in urine $\times$ volume of urine) concentration in blood

becomes $\frac{Q_{t}}{B}$ where $Q_{t}$ is the quantity of radioiodine accumulated in the thyroid in an appropriate interval of time and $B$ is the mean concentration of radioiodide in the blood during the same interval. $Q_{t}$ is obtained by taking the difference between the quantity of radioiodine observed in the thyroid at the start of the interval and the quantity present at the end of the interval. Since the concentration of radioiodide in the blood decreases exponentially with time, the mean concentration of radioiodide in blood for the interval must be evaluated from the formula

$$
B=\frac{B_{1}-B_{2}}{\log _{e} B_{1}-\log _{e} B_{2}},
$$

where $B_{1}$ and $B_{2}$ are the observed concentrations at the beginning and end of the interval respectively. The clearances in Table $\mathrm{V}$ were all based on observations two and six hours after administration of the dose.

$$
\begin{aligned}
& \quad \text { Volume of distribution }=\frac{\text { clearance }}{\text { accumulation rate }} \times \frac{60}{1,000} \\
& \times 100
\end{aligned}
$$

the clearances and the accumulation rates vary more or less proportionately in the cases studied, and also that the volume of distribution appears to be somewhat larger than the usual value for the volume of extracellular fluid in some cases. The fact that volume of distribution may vary considerably from case to case indicates that accumulation rate may not reflect clearance with complete fidelity and therefore may not be entirely accurate as an absolute measure of iodineaccumulating function. However, accumulation rate may be the most direct and quantitative measure of this function which can be determined from in vivo observations alone.

The nature of the iodine-accumulating function. It is important to note that the function of the thyroid appraised directly or indirectly by any of the measures which have been discussed is a very particular one; namely, the accumulation of iodine in the thyroid. Such accumulation probably reflects in large measure the formation of diiodotyrosine and thyroxine and their storage in the reservoir of the thyroid follicle.

If one could assume that the total quantity of iodine contained in the thyroid was more or less constant for any short period (that is, did not fluctuate rapidly), then accumulation rate might reflect the rate at which thyroid hormone was being secreted and perhaps might serve as an index of thyroid turnover rate. However, some of the earliest work of Hamilton and Soley suggests that there could be a dangerous fallacy in such assumptions. They observed in two cases of nodular goiters and hypothyroidism that despite clinical evidences which would lead one to infer that the secretion of thyroid hormone by the thyroid was inadequate or nil, the thyroids collected radioiodine in quantities similar to those collected in exophthalmic goiter. We have observed a similar disparity in certain myxedematous states accompanying thyroiditis and cyanate goiter. Until more is known, therefore, it is probably best to regard iodine accumulation by the thyroid as a function which does not necessarily or invariably parallel the secretion of thyroid hormone.

The iodide-concentrating function measured by Stanley and Astwood (3) in the human thyroid blocked with mercaptoimidazol must be regarded as a thyroidal function involving iodine distinct 
from iodine accumulation as the term has been applied here. The iodine concentrated by the blocked thyroid has been shown to be in the inorganic state and probably in some sort of equilibrium with the blood: The rather rapid decrease of thyroidal radioiodine observed in the blocked thyroid takes place at a rate roughly comparable to the disappearance of radioiodine from the blood as we have observed it in cases of myxedema. These considerations lead one to predict that the kinetic relationships shown to exist between radioiodine in urine, blood and thyroid in this and previous papers will not apply in the case of the phenomenon described by Stanley and Astwood.

Finally, it must be emphasized that the methods employed in this paper and the papers which have preceded it for the estimation of rates of disposal of radioiodine in urine, thyroid and other tissues are based on a model which is undoubtedly oversimplified. The values obtained may contain errors arising from factors which complicate the picture, such as the rate of absorption from the gastro-intestinal tract, the time required for equilibrium to become established between the blood and body fluids, and the rate of secretion of radioiodine from the thyroid once it has been accumulated. It is essential, therefore, to regard the values reported as at best first approximations. Nevertheless, the consistency with which independent observations on urine, thyroid, blood and peripheral tissues can be made to match one another in a simple scheme is some justification for assuming that the various interrelationships which have been discussed may be valid ones.

\section{SUMMARY}

An empirical method has been described for the measurement in microcuries of radioiodine collected by the human thyroid gland after oral adninistration.

The iodine-accumulation rate of the thyroid is defined as the proportional rate at which the thyroid accumulates iodine. Two alternative methods have been described for estimating this value. A basis has been given for assuming that this rate applies to all of the iodide in the blood and body fluids in equilibrium with the blood.

Mean iodine-accumulation rate by the thyroid was $2.4 \pm 0.7$ per cent per hour in five patients having normal thyroid function and low-grade thyroid tumors, $4.6 \pm 1.3$ per cent per hour in seven patients having adenomatous goiter without hyperthyroidism and $20.2 \pm 5.6$ per cent per hour in seven patients having hyperthyroidism.

Accumulation rate has been compared with measurements of the quantity of radioiodine excreted in urine, the quantity collected in the thyroid and the disappearance rate of radioiodine from the blood. Accumulation rate appears to be a more significant measure of iodine-accumulating function of the thyroid than any of these.

The rate of extrarenal disposal of iodide, estimated from the curve of urinary excretion of radioiodine, closely reflects accumulation rate in cases of normal or increased thyroid activity. It appears in such situations to be a valid index of accumulation rate, despite some inaccuracy resulting from variations in the disposal of iodide by tissues other than thyroid or kidneys.

Accumulation rate may be less significant as a measure of accumulating function than thyroidal iodide clearance, determined directly from in vivo observations over the thyroid obtained simultaneously with determinations of the concentration of radioiodine in plasma.

\section{BIBLIOGRAPHY}

1. Vanderlaan, J. E., and Vanderlaan, W. P., The iodide concentrating mechanism of the rat thyroid and its inhibition by thiocyanate. Endocrinology, 1947, 40, 403.

2. Taurog, Alvin, Chaikoff, I. L., and Feller, D. D., The mechanism of iodine concentration by the thyroid gland: its non-organic iodine-binding capacity in the normal and propylthiouracil-treated rat. J. Biol. Chem., 1947, 171, 189.

3. Stanley, M. M., and Astwood, E. B., The accumulation of radioactive iodide by the thyroid gland in normal and thyrotoxic subjects and the effect of thiocyanate on its discharge. Endocrinology, 1948, 42, 107.

4. Hamilton, J. G., and Soley, M. H., Studies in iodine metabolism of the thyroid gland in situ by the use of radio-iodine in normal subjects and in patients with various types of goiter. Am. I. Physiol., 1940, 131, 135.

5. Luellen, T. J., Keating, F. R., Jr., Williams, M. M. D., Berkson, Joseph, Power, M. H., and McConahey, W. M., Relative measurement in vivo of accumulation of radioiodine by the human thyroid gland: comparison with radioactivity in peripheral tissues. J. Clin. Inspect., 1949, 28, 20 \%. 
6. Hertz, Saul, Roberts, Arthur, and Salter, W. T., Radioactive iodine as an indicator in thyroid physiology. IV. The metabolism of iodine in Graves' disease. J. Clin. Invest., 1942, 21, 25.

7. Taurog, Alvin, and Chaikoff, I. L., The metabolic interrelations of thyroxine and diiodotyrosine in the thyroid gland as shown by a study of their specific activity-time relations in rats injected with radioactive iodine. J. Biol. Chem., 1947, 169, 49.

8. Hamilton, J. G., Soley, M. H., Reilly, W. A., and Eichorn, K. B., Radioactive iodine studies in childhood hypothyroidism. Am. J. Dis. Child., 1943, 66, 495.

9. Hertz, Saul, Radioactive iodine as indicator in thyroid physiology; observations on rabbits and on goiter patients. Am. J. Roentgenol., 1941, 46, 467.

10. Seidlin, S. M., Marinelli, L. D., and Oshry, Eleanor, Radioactive iodine therapy; effect on functioning metastases of adenocarcinoma of the thyroid. J. A. M. A., 1946, 132, 838.
11. Quimby, Edith H., and McCune, D. J., Uptake of radioactive iodine by normal and disordered thyroid gland in children; a preliminary report. Radiology, 1947, 49, 201.

12. Stanley, M. M., and Astwood, E. B., Determination of the relative activities of antithyroid compounds in man using radioactive iodine. Endocrinology, 1947, 41, 66.

13. Rawson, R. W., Evans, R. D., Means, J. H., Peacock, W. C., Lerman, J., and Cortell, R. E., The action of thiouracil upon the thyroid gland in Graves' disease. J. Clin. Endocrinol., 1944, 4, 1.

14. Keating, F. R., Jr., Power, M. H., Berkson, Joseph, and Haines, S. F., The urinary excretion of radioiodine in various thyroid states. J. Clin. Invest., 1947, 26, 1138.

15. McConahey, W. M., Keating, F. R., Jr., and Power, M. H., The behavior of radioiodine in the blood. J. Clin. Invest., 1949, 28, 191. 